\title{
KETERLIBATAN MASYARAKAT DALAM MEMBANGUN HARMONI SOSIAL MUSLIM-KRISTEN PRA DAN PASCA KONFLIK ETNIK DI MALUKU
}

\author{
Nathalia Debby Makaruku \\ Universitas Kristen Satya Wacana Salatiga, Indonesia \\ E-mail:752018048@student.uksw.edu \\ Izak Y. M. Lattu \\ Universitas Kristen Satya Wacana Salatiga, Indonesia \\ E-mail: lattu@staff.uksw.edu \\ Tony Robert C. Tampake \\ Universitas Kristen Satya Wacana Salatiga, Indonesia \\ E-mail: tony.robert@staff.uksw.edu
}

\begin{abstract}
The aim of the article is to give a sociological description and analysis toward the civic engagement of Taniwel Timur in building social harmony between Muslims and Christians, pre and post-conflict in Maluku. There are two main important points which are, the history of Muslims-Christians' engagement in building a relationship and social interaction, and MuslimsChristians' engagement becomes the basic in building harmonious social relationships. This research employed a qualitative research method through a structured interview technique with key informants, observation, and library study. The result of the research found that; first, the Muslims-Christians engagement divided into two which are the association form of civic engagement such as religious institutions, custom and government and everyday form of civic engagement. Second, the MuslimsChristians' engagement was based on strong brotherhood, cooperation with many parties, strong traditions and mutual trust. Association form and everyday form of civic engagement had the same position to build a strong social system. It also created a sphere of solidarity, justice, and fraternity. In conclusion, Taniwel Timur's society can construct a harmonious social life.
\end{abstract}

Keywords: Civic engagement; Muslims and Christians relationship; social harmony. 


\section{Pendahuluan}

Maluku mengalami konflik kekerasan pada tahun 1999 yang menyebabkan perubahan besar terjadi di setiap sistem interaksi sosial masyarakat Muslim-Kristen. Konflik yang terjadi diawali dengan pertengkaran kecil antara supir bus Kristen Ambon dengan penumpang pendatang Muslim Bugis. Peristiwa ini memicu konflik interkomunal yang terjadi selama tiga tahun antara para pendatang dan penduduk asli. Peristiwa ini juga berperan mendorong kekerasan yang terjadi antara orang-orang Muslim Ambon asli dan Kristen Ambon asli dalam skala yang belum pernah terjadi pada periode modern. ${ }^{1}$ Konflik kekerasan yang mengatasnamakan agama ini menyebabkan hancurnya hubungan sosial, kepercayaan, dan nilai-nilai adat, bahkan menciptakan segregasi wilayah MuslimKristen di Maluku hingga sekarang.

Menurut Bartels, konflik komunal di Maluku hanyalah sepenggal episode dari riwayat panjang kerukunan di negeri ini. Sebelumnya, perbedaan agama jarang sekali menjadi hambatan kebersamaan dalam kehidupan sosial. ${ }^{2}$ Secara historis dan kultural, di Maluku belum pernah mengalami konflik agama. Hal ini disebabkan oleh warisan budaya Maluku yang bernama pela gandong. ${ }^{3}$ Budaya pela gandong mengajarkan bahwa masyarakat Maluku yang terdiri atas umat Muslim dan umat Kristen berasal dari satu "akar," sehingga harus saling membantu dalam kehidupan sosial dan dilarang saling menyakiti, apalagi saling membunuh. ${ }^{4}$ Namun demikian, ketentraman dan kedamaian yang dijaga oleh masyarakat Maluku selama ini dapat dihancurkan oleh kekerasan yang mengatasnamakan agama.

1 Dieter Bartels, Di Bawah Naungan Gunung Nunusaku; Muslim Kristen Hidup Berdampingan di Maluku Tengah (Jakarta: Kepustakaan Populer Gramedia, 2017), xxxii-xxxiv.

2 Ibid., xxiii.

${ }^{3}$ Pela adalah hubungan antara dua atau tiga negeri di Maluku yang terjadi karena ada peristiwa sejarah yang dialami oleh masyarakat negeri itu. Pela dapat diartikan juga sebagai sumpah dan janji atau ikatan perjanjian antar negeri-negeri. Pela terbagi atas tiga, yakni Pela Darah (pela ini terjadi karena adanya peperangan), Pela Tampa Sirih (terjadi karena sebuah peristiwa sejarah yang pernah dialami, misalnya pela antara orang Batu Merah dan Orang Paso), dan Pela Gandong (hubungan antara dua negeri atau lebih karena ada hubungan genealogi atau pertalian darah).

${ }^{4}$ H. A. Payitno, Etika Kemajemukan; Solusi Strategis Merenda Kebersamaan dalam Bingkai Masyarakat Majemuk (Jakarta: Penerbit Universitas Trisakti, 2004), 123. 
Konflik yang mengatasnamakan agama hampir terjadi di seluruh daerah Maluku, termasuk Taniwel. Namun, daerah-daerah yang berada di bagian Timur tidak mengalami konflik. Taniwel Timur merupakan masyarakat plural, yang terdiri dari suku Wemale (Suku asli) dan Ambon, Ternate, Tidore, Buton, Bacan, Bugis, Batak, dan Jawa. Keberagaman ini terjadi karena kedatangan orang-orang dari luar Taniwel Timur yang melakukan ekspansi kekuasaan seperti yang dilakukan oleh Kesultanan Ternate-Tidore dan perdagangan yang dilakukan oleh suku Jawa, Bugis, dan Buton. Dalam perjalanan waktu, para pendatang ini merasa nyaman dan menetap di Taniwel Timur hingga sekarang.

Pluralitas yang terjadi di Taniwel Timur disebabkan juga oleh suatu proses asimilasi melalui migrasi dan perkawinan campur. Secara sosiologis, proses asimilasi ini semakin memperkuat keberadaan atau status sosial pendatang pada masyarakat Taniwel Timur. Konsekuensi sosiologisnya adalah mereka diterima sebagai bagian sah secara adat pada masyarakat Taniwel Timur. Secara sosiologis dan emosional, asimilasi ini menciptakan ikatan sosial yang kuat, apalagi didukung oleh sistem kemasyarakatan Taniwel Timur yang dilandasi hubungan kekeluargaan dan kekerabatan yang erat.

Selain pluralitas etnis di atas, kenyataan objektif lainnya yang terlihat secara jelas dalam konteks masyarakat Taniwel Timur adalah pluralitas agama. Dari segi kehidupan keagamaan, masyarakat Taniwel Timur terdiri dari tiga agama besar yaitu Kristen Protestan, Islam, dan Hindu. Agama Hindu merupakan agama suku atau agama nenek moyang zaman hindu atau "zaman kafir." Istilah ini digunakan untuk penganut kepercayaan animistik. ${ }^{5}$ Mayoritas masyarakat Taniwel Timur memeluk agama Kristen Protestan dan hidup berdampingan secara rukun dan damai dengan pemeluk agama lain. Secara sosiologis, masyarakat Taniwel Timur hidup bersama sebagai komunitas sosial yang saling menerima, menghargai, dan membaur satu sama lain dalam kegiatan-kegiatan keagamaan maupun kegiatan sosial.

Konflik terjadi di berbagai daerah dengan skala yang cukup besar tetapi tidak di daerah Taniwel Timur yang mampu menciptakan harmoni sosial. Masyarakat Taniwel Timur berupaya menjaga kedamaian dan ketentraman melalui keterlibatan

${ }^{5}$ Bartels, Di Bawah Naungan, 437. 
masyarakat dalam berbagai aspek kehidupan. Keterlibatan masyarakat Muslim-Kristen dilakukan dengan dua cara, yaitu melalui relasi setiap hari dan hubungan asosiasi. Relasi setiap hari berarti masyarakat Muslim-Kristen di Taniwel Timur hidup berdampingan, saling mengunjungi, makan bersama, anak-anak bermain bersama serta melakukan interaksi yang baik di antara kedua komunitas. Relasi kedua dibangun dalam hubungan asosiasi masyarakat, lembaga keagamaan, komunitas adat, dan lembaga pemerintahan. Realitas ini menunjukkan bahwa keterlibatan masyarakat Muslim-Kristen di Taniwel Timur mampu menciptakan kehidupan damai, saling melindungi dan membantu pra dan pasca konflik etnik Maluku.

Para peneliti terdahulu telah menulis tentang hubungan Muslim-Kristen dalam konflik etnik Maluku (Birgit Brauchler, 2009; Izak Lattu, 2014; Kirsten E. Schulze, 2017; dan Sharon Pattiasina, 2018). Setelah mempelajari hasil penelitian ini, tidak ada hasil penelitian yang membahas tentang keterlibatan sosial (civic engagement) sebagai upaya membangun harmoni sosial MuslimKristen di Maluku pra dan pasca konflik etnik. Beberapa penelitian berfokus kepada ethnic conflict and the revival of tradition sebagai upaya untuk mengatasi perbedaan antaragama dan menciptakan harmoni sosial. Penelitian lain juga berfokus pada memori kolektif yang diartikulasikan dalam bentuk budaya pela gandong, cerita rakyat, folksong, narasi lisan dan ritual-ritual sebagai upaya membangun perdamaian dan solidaritas kolektif dalam perbedaan agama yang disatukan oleh budaya. Artikel ini berupaya untuk menggali lebih dalam tentang interaksi Muslim-Kristen dalam wujud keterlibatan masyarakat sebagai upaya membangun harmoni sosial.

Artikel ini menggunakan teori civic engagement menurut Putnam dan Varshney serta teori civil sphere menurut Alexander. Civic engagement mengacu pada cara-cara di mana suatu masyarakat berpartisipasi dalam kehidupan komunitas untuk meningkatkan kondisi orang lain atau membantu membentuk masa depan komunitas yang lebih baik. Sedangkan civil sphere merupakan ruang di mana solidaritas dan keadilan diciptakan dan dipelihara. Civil sphere menjadi ruang di mana setiap anggota masyarakat diikat dalam suatu perasaan keterhubungan yang mendalam, perasaan bersama dan komitmen yang kuat. Teori civic engagement dan civil sphere digunakan untuk mengamati dan menganalisa keterlibatan 
masyarakat Muslim-Kristen di Taniwel Timur dalam upaya membangun harmoni sosial.

Berdasarkan latar belakang di atas, artikel ini bermaksud untuk menjelaskan bagaimana masyarakat Muslim-Kristen Taniwel Timur membangun harmoni sosial di tengah-tengah konflik etnik. Fokus artikel ini adalah menganalisis dan menjelaskan keterlibatan masyarakat Muslim-Kristen Taniwel Timur dalam membangun harmoni sosial pra dan pasca konflik etnik Maluku. Artikel ini menggunakan pendekatan kualitatif-deskriptif dengan empat lokus penelitian, yaitu di Desa Makububui, Desa Sukaraja, Desa Lumapelu dan Desa Uwen. Pembahasan dalam artikel ini dilakukan dengan menggunakan metode pengumpulan data berupa wawancara terstruktur dengan informan kunci; pemerintah desa, tokoh adat dan tokoh agama, observasi non partisipan, dan studi pustaka.

\section{Harmoni Sosial dalam Perspektif Civil Sphere dan Civic Engagement}

Manusia sebagai makhluk sosial tidak dapat hidup sendiri atau hidup tanpa terlibat dengan orang lain. Setiap individu membutuhkan individu lain tidak hanya untuk saling tolongmenolong, tetapi juga untuk membangun komunitas sosial yang saling mendukung dan bekerja sama demi mencapai tujuan yang diinginkan. Salah satu tujuan bersama yang diinginkan oleh setiap komunitas sosial yaitu membangun ruang-ruang toleransi dan solidaritas yang dapat memfasilitasi kehidupan bersama dalam suatu tatanan sosial. Ruang-ruang ini dalam bahasa Jeffrey Alexander disebut civil sphere atau ruang/ranah sosial.

Pemahaman tentang ruang sipil perlu disinergikan dengan pemahaman masyarakat sipil. Menurut Alexander, masyarakat sipil dipahami sebagai ruang atau subsistem masyarakat yang secara analitik dan empiris terpisah dari bidang politik, ekonomi, keluarga, dan keagamaan. Masyarakat sipil adalah ruang solidaritas yang ditandai oleh komunitas universal di mana hubungan orang-orang didorong oleh wacana demokratis, kesopanan, kejujuran, keterbukaan, kritik konstruktif dan saling menghormati. ${ }^{6}$ Ruang sipil juga dipahami sebagai ruang di mana solidaritas dan keadilan

${ }^{6}$ Jeffrey C. Alexander, The Civil Sphere (New York: Oxford University Press, 2006), 53. 
diciptakan dan dipelihara. Sistem tatanan ini merupakan struktur perasaan yang memberikan anggotanya rasa keterhubungan yang mendalam, perasaan bersama, dan komitmen simbolik. Hal inilah yang menghasilkan identifikasi timbal balik menyatukan orangorang di seluruh kelas, agama, etnis, ras, dan divisi gender. Dalam ruang ini, baik hal individu atau kolektif dilindungi dengan baik. ${ }^{7}$

Alexander memahami ruang sipil dengan membagi masyarakat sipil dalam tiga tipe ideal. Pertama, masyarakat sipil I, pemahaman yang berangkat dari Locke, Ferguson, Smith, Rousseau, Hegel dan Tocqueville adalah; yaitu konsep yang sedikit menyebar, lembaga sukarela, agama publik, individu dan hampir setiap bentuk hubungan yang menciptakan ikatan kepercayaan. ${ }^{8}$ Kedua, masyarakat sipil II yang berangkat dari pemikiran Marx yang sempit dan instrumental; bahwa suprastruktur hukum dan politik di atas sistem pasar kapitalis. Dalam masyarakat sipil II ini, cita-cita yang dibangun adalah bertahan dalam solidaritas proletariat dan instrumentalisme atau "perang posisi" menurut Gramsci." Ketiga, masyarakat sipil III, ini merupakan tipe masyarakat yang direkomendasikan oleh Alexander yang kemudian membentuk ruang sipil atau, dalam bahasanya, "ruang solidaritas sosial." Masyarakat sipil III merupakan lingkungan solider, di mana satu jenis komunitas didefenisikan sebagai kebudayaan dan pada tingkat tertentu ditegakkan secara kelembagaan. Komunitas dalam masyarakat sipil III ini didukung oleh opini publik, kode budaya yang mendalam, organisasi hukum, jurnalistik, dan asosiasi yang khas. ${ }^{10}$

Ruang sipil yang dibangun adalah teori dan model empirisanalitik dari produksi solidaritas dan kesamaan. Dengan kata lain, model masyarakat demokratis yang lebih memperhatikan perasaan bersama dan komitmen bersama. Sehingga ruang ini dapat memfasilitasi orang-orang yang berbicara, berpikir, merasakan, dan bertindak tentang masalah politik dan lebih umum tentang kehidupan sosial yang demokratis. ${ }^{11}$

\footnotetext{
${ }^{7}$ Aldon Morris, "Naked Power and Civil Sphere Review Jeffrey Alexander 'The Ccivil Sphere,"' The sociological Quarterly, Vol. 48, No. 4 (2007), 617.

8 Alexander, The Civil Sphere, 25.

${ }^{9}$ Ibid., 31.

${ }^{10}$ Ibid., 43.

11 Ibid.
} 
Berdasarkan penjelasan di atas, ruang sipil dapat diartikan sebagai oasis nilai-nilai demokrasi dan ikatan solidaritas yang ditopang oleh seperangkat institusi komunikatif dan regulator. Ruang sipil dikelilingi oleh lingkungan non-sipil dan ruang partikularistik termasuk negara, ekonomi, keluarga, agama dan komunitas. Berbicara secara demokratis, ruang sipil lebih unggul karena dalam mandat normatif yang ditetapkan oleh masyarakat demokratis, keadilan dalam ruang sipil mengalahkan ruang-ruang yang lain. ${ }^{12}$ Dengan demikian menjadi jelas pernyataan Alexander bahwa masyarakat sipil penuh dengan kontradiksi dan terpecahpecah sehingga ruang sipil selalu tidak lengkap dan terfragmentasi. Namun demikian, ruang sipil selalu menyediakan alat untuk mengkalibrasi ulang demokratisasinya sendiri. Hal ini dilakukan oleh gerakan-gerakan sosial melalui keterlibatan masyarakat (civic engagement) dengan menggunakan nilai-nilai dan wacana sipil dari ruang sipil demi membasmi ruang kontradiksi dan memperluas jangkauan solidaritas dan keadilan. ${ }^{13}$

Keterlibatan masyarakat atau civic engagement mengacu pada cara-cara di mana masyarakat berpartisipasi dalam kehidupan komunitas untuk meningkatkan kondisi orang lain atau membantu membentuk masa depan komunitas. Istilah civic engagement banyak digunakan sampai saat ini terutama dalam studi-studi sosial budaya dan politik. Secara dimensi politik dan kolektif, civic engagement merujuk pada akar kata "civic" dari bahasa Latin yang berarti "kota" atau "warga." Civic engagement berarti menemukan kembali politik, kehidupan polis atau kota di mana laki-laki dan perempuan berbicara dan bertindak bersama-sama sebagai warga negara. Kata "civic" jika dihubungkan dengan "keterlibatan," maka kata ini menyiratkan pekerjaan yang dilakukan secara publik dan bermanfaat bagi publik. Dengan demikian, civic engagement dapat diartikan sebagai pekerjaan yang dilakukan secara bersama-sama untuk kepentingan orang banyak. ${ }^{14}$

Penggunaan istilah keterlibatan masyarakat (civic engagement) cukup luas dan menarik dalam membahas masalah sosial budaya. Robert Putnam menggunakan istilah keterlibatan masyarakat dalam

\footnotetext{
12 Ibid., 34.

${ }_{13}$ Morris, Naked Power and Civil Sphere, 617-618.

14 Adlar P. Richard dan Judy Goggin, "What Do We Mean By 'Civic Engagement?," Journal of Transformative Education, Vol. 3, No. 3 (2005), 237.
} 
penjelasannya mengenai Modal Sosial. Dalam teori modal sosial, konsep-konsep keterlibatan masyarakat dan kepercayaan sosial menjadi sangat penting. Premis dasar teori modal sosial adalah bahwa koneksi sosial memiliki nilai dan memberikan dasar bagi kohesi sosial. Ini pada gilirannya berarti bahwa, hubungan sosial di antara masyarakat membantu untuk mempromosikan kehidupan bersama (demokrasi) yang kuat dan efektif. Istilah "modal sosial" terkait dengan mengukur kepercayaan sosial yang didasarkan pada keterlibatan masyarakat dalam kehidupan sosial. Putnam mendefinisikan modal sosial sebagai "fitur kehidupan sosial; jaringan, norma, dan kepercayaan yang memungkinkan masyarakat bertindak bersama secara lebih efektif untuk mengejar tujuan bersama. Modal sosial secara singkat mengacu pada hubungan sosial, norma, serta kepercayaan yang menyertainya. ${ }^{15}$

Teori modal sosial memiliki asumsi korelasi antara kepercayaan sosial dengan keterlibatan masyarakat (civic engagement). Kepercayaan sosial dengan keterlibatan masyarakat saling terhubung satu dengan yang lain. Putnam menyatakan bahwa setiap penilaian tren dalam modal sosial harus selalu mencakup kesukarelaan, filantropi, dan altruisme. ${ }^{16}$ Dengan demikian, modal sosial memperkuat jaringan, norma hubungan masyarakat untuk tujuan membangun kepercayaan sosial. Berdasarkan hal tersebut, konsekuensi positif dari keterlibatan masyarakat dalam modal sosial dapat dilihat sebagai peningkatan tingkat kepercayaan dalam hubungan masyarakat. Oleh karena itu, modal sosial ada dan tertanam dalam hubungan masyarakat, sehingga jika individu kurang terlibat dalam komunitas maka dapat disimpulkan bahwa ada kehilangan hubungan dalam suatu masyarakat. ${ }^{17}$

Definisi Putnam mengenai civic engagement atau keterlibatan masyarakat mencakup dua kegiatan; pertama, kegiatan sosial informal seperti mengunjungi teman, keluarga, bermain kartu, dan sebagainya. Kedua, kegiatan formal seperti layanan komisi, pemilihan umum, partisipasi masyarakat dalam kegiatan politik, kegiatan keagamaan, dan sebagainya. Kegiatan-kegiatan yang

\footnotetext{
${ }^{15}$ Roberth Putnam, Bowling Alone: The Collapse and Revival of American Community (New York: Simon \& Schuster, 2000), 664-665.

16 Ibid., 117.

17 Ami Doolittle dan Anna C. Faul, "Civic Engagement Scale: A Validation Study," SAGE Open, Vol. 3, No. 3 (2013), 02.
} 
merujuk pada keterlibatan masyarakat ini menjadi kekuatan bagi pembangunan modal sosial sebagai dasar bagi kehidupan bersama. Dengan demikian, keterlibatan masyarakat adalah tindakan individu dan kolektif yang dirancang untuk mengidentifikasi dan menangani masalah-masalah dari perhatian publik. Keterlibatan masyarakat dapat terjadi dalam bentuk kesukarelaan individu hingga keterlibatan dalam suatu organisasi. Aktivitas ini juga mencakup upaya secara langsung dalam mengatasi masalah, bekerja dalam komunitas untuk mengatasi masalah dan berinteraksi dengan lembaga-lembaga perwakilan dalam menyelesaikan masalah tertentu. Keterlibatan masyarakat mencakup berbagai kegiatan spesifik seperti bekerja di dapur umum, melayani asosiasi lingkungan, menulis surat kepada pejabat terpilih atau memberikan suara dalam pemilihan umum. ${ }^{18}$

Sejalan dengan pemikiran Putnam, Varshney membagi keterlibatan sipil dalam dua bentuk, yaitu bentuk asosiasi dan bentuk sehari-hari. Pembagian ini dilakukan oleh Varshney ketika menjelaskan tentang hubungan Muslim-Hindu di India. Dalam bukunya Ethnic Conflict and Civic Life: Hindu Muslim in India, Varshney berusaha membangun hubungan integral antara struktur masyarakat sipil di satu sisi dengan kekerasan etnis atau komunal di sisi lain. Untuk lebih tepatnya, fokus penulisannya adalah jaringan kehidupan sipil antarkomunitas. Jaringan-jaringan ini pada gilirannya dipecahkan menjadi dua; asosiasional dan kuantum. Bentuk pertama dan yang paling utama yaitu asosiasi dari keterlibatan masyarakat, dan bentuk kedua yaitu kuantum atau keterlibatan sehari-hari dalam hubungannya dengan keterlibatan masyarakat. Bentuk pertama bisa berupa asosiasi bisnis, organisasi profesional, klub membaca, klub film, klub olahraga, organisasi festival, serikat pekerjaan, partai politik, lembaga keagamaan dan sebagainya. Sementara bentuk interaksi setiap hari seperti keluarga Hindu dan Muslim yang saling mengunjungi, makan bersama, berpartisipasi dalam festival, membiarkan anak-anak bermain bersama. Kedua bentuk ikatan ini jika terbentuk dengan kuat maka akan mempromosikan kedamaian. Sebaliknya, kurangnya keterlibatan dalam masyarakat dapat menimbulkan kekerasan komunal. ${ }^{19}$

\footnotetext{
18 Richard dan Goggin, "What Do We Mean," 239.

19 Ashutosh Varshney, Ethnic conflict and Civic Life: Hindu and Muslims in India (London: Yale University Press, 2002), 3-4.
} 
Berdasarkan kasus konflik komunal yang dialami oleh masyarakat Muslim dan Hindu di India, Varshney menjelaskan bahwa keterlibatan masyarakat dalam bentuk asosiasi dapat menjadi bentuk terkuat dalam membangun hubungan yang baik dalam masyarakat plural. Untuk menjelaskan tentang alasan keterlibatan asosiasional sebagai benteng perdamaian yang lebih kokoh dari pada keterlibatan sehari-hari, Varshney mengemukakan mekanisme yang menghubungkan keterlibatan masyarakat (civic engagement) dengan konflik etnis berikut ini.

Pertama, keterlibatan masyarakat ini dapat mempromosikan komunikasi antara anggota komunitas agama yang berbeda, sehingga keterlibatan masyarakat ini memungkinkan perdamaian di tingkat lingkungan. Keterlibatan masyarakat yang dilakukan secara rutin memungkinkan orang berkumpul dan membentuk organisasi di saat-saat penuh ketegangan. Organisasi-organisasi semacam ini, meskipun singkat, ternyata sangat signifikan. Organisasi seperti ini dapat disebut sebagai kelompok perdamaian yang terdiri dari anggota kedua komunitas. Organisasi ini mengawasi lingkungan, membunuh rumor, memberikan informasi kepada pemerintah lokal dan memfasilitasi komunikasi antarmasyarakat ketika terjadi ketegangan. Interaksi atau keramahtamahan selanjutnya dapat membentuk organisasi pengelolaan krisis yang tepat.

Kedua, bentuk keterlibatan masyarakat secara asosiasi lebih kokoh dari pada bentuk sehari-hari dalam mengalami ketegangan etnis. Hal ini disebabkan oleh organisasi yang hidup dapat melayani kebutuhan ekonomi, budaya, dan sosial dari kedua komunitas. Oleh sebab itu, dukungan untuk perdamaian komunal tidak hanya cenderung kuat tetapi juga lebih solid. Bentuk keterlibatan asosiasi banyak dijumpai di kehidupan perkotaan yang berbeda dengan keterlibatan sehari-hari yang banyak ditemukan di kehidupan pedesaan. Keterlibatan sehari-hari atau keterlibatan informal sering berhasil di desa-desa dalam menjaga kedamaian, tetapi tidak di kota-kota yang cenderung kurang saling berhubungan dan lebih anonim. ${ }^{20}$ Berdasarkan kedua mekanisme ini, Varshney meyakini bahwa keterlibatan masyarakat dalam bentuk asosiasi dapat menjadi alat untuk terhindar dari konflik etnik.

${ }^{20}$ Ibid., 9-10. 


\section{Sejarah Civic Engagement Muslim-Kristen di Taniwel Timur}

Civic Engagement atau keterlibatan masyarakat sangat penting dalam sebuah komunitas untuk menciptakan kekuatan bagi komunitas tersebut. Tidak hanya cukup pada menciptakan kekuatan, tetapi dengan keterlibatan masyarakat, sebuah komunitas dapat bertahan dari konflik atau kekerasan yang sewaktu-waktu dapat terjadi. Keterlibatan masyarakat yang terjadi di Taniwel Timur bukan merupakan kenyataan yang baru. Keterlibatan masyarakat Muslim-Kristen di Taniwel Timur telah terjadi kurang lebih sejak abad ke 13-14 M ketika negeri-negeri ini dibentuk. Dengan demikian, dapat dikatakan bahwa keterlibatan masyarakat Taniwel Timur menjadi bagian dari sejarah panjang terbentuknya komunitas-komunitas Muslim-Kristen di Taniwel Timur.

Sejarah keterlibatan masyarakat Muslim-Kristen di Taniwel Timur dibagi ke dalam beberapa bagian, yaitu; Sejarah perjumpaan Muslim-Kristen di Taniwel Timur (Kekuasaan Ternate-Tidore dan Kekuasaan Belanda), Pergolakan RMS (Republik Maluku Selatan) tahun 1950, Konflik Maluku 1999, dan kehidupan sosial masyarakat Muslim-Kristen pada masa kini. Pertama, secara historis, perjumpaan Muslim-Kristen di Taniwel Timur dimulai ketika Kesultanan Muslim dari Ternate dan Tidore melakukan ekspansi wilayah kekuasaan ke Pulau Seram (Maluku). Kesultanan Muslim kemudian menguasai daerah pesisir Pulau Seram sekitar akhir abad ke-13 M. Pada awal abad ke-14 M terjadi perang perebutan wilayah di antara penduduk asli Taniwel Timur. Berdasarkan sejarah, perang di antara penduduk asli telah berlangsung jauh sebelum kekuasaan Islam di Pulau Seram, tetapi perang tersebut berlangsung dalam skala kecil dan terjadi dalam waktu-waktu tertentu. Perang tersebut dijuluki sebagai "perang batu" (perang yang menggunakan batu untuk saling melukai dan merusak properti seperti rumah dan fasilitas umum). ${ }^{21}$

Pada masa kekuasaan Kesultanan Muslim, "perang batu" muncul kembali dengan skala yang besar dan dengan tujuan perebutan wilayah kekuasaan. Perang yang berlangsung lama, membuat keresahan bagi Raja yang menguasai daerah pesisir pada masa itu. Sebagai upaya perdamaian dikirimlah beberapa utusan ke negeri-negeri yang berkonflik. Utusan tersebut terdiri dari suku asli Pulau Seram dan pendatang dari Ternate-Tidore yang beragama

${ }^{21}$ Danie Meute (Tokoh adat Desa Uweng), Wawancara, Taniwel Timur, 2020.. 
Muslim. Perjumpaan ini menjadi perjumpaan pertama Muslim dan Agama Hindu (Agama Suku) di Taniwel Timur. Kedatangan masing-masing utusan tersebut kemudian menciptakan kedamaian di antara penduduk asli, sehingga mereka lalu diterima dan tinggal di Taniwel Timur. Penerimaan tersebut dilakukan secara adat sebagai penerimaan terhadap saudara atau keluarga. Penerimaan ini juga dilakukan dengan pemberian wilayah sebagai tempat tinggal dan juga lahan untuk bertani. ${ }^{22}$ Kedatangan utusan yang membawa kedamaian bagi penduduk asli dan penerimaan yang dilakukan penduduk asli bagi para pendatang secara sosiologis dapat dikatakan sebagai keterlibatan masyarakat pertama yang dilakukan oleh Taniwel Timur yang plural.

Keterlibatan masyarakat yang terjadi di Taniwel Timur semakin erat dengan kehadiran Belanda. Kedatangan Belanda dengan tujuan menguasai wilayah perdagangan di Pulau Seram dan penyebaran Injil juga mempengaruhi kehidupan masyarakat Taniwel Timur. Pada mulanya, pengaruh ini banyak terjadi ketika Belanda menerapkan sistem kerja paksa yaitu pembuatan jalanjalan dari daerah pesisir ke daerah pegunungan. Ketika kerja paksa ini diterapkan, negeri-negeri di Taniwel Timur baik Muslim maupun Hindu saling bekerja sama untuk menyelesaikan pekerjaan tersebut. Pembuatan jalan dari daerah pesisir sampai ke daerah pegunungan bukan hal yang mudah, sehingga negeri-negeri tersebut membuat sistem pembagian kerja. Terdapat dua kelompok kerja pada waktu itu, yaitu kelompok yang bersedia menyiapkan bahan makanan dan membuat makanan dan kelompok pekerja. Dengan pembagian kerja yang sederhana, pekerjaan yang berat dapat diselesaikan. ${ }^{23}$

Pada kesempatan selanjutnya, keterlibatan masyarakat Taniwel Timur yang kedua pada masa kolonialisme, terlihat pada proses penyebaran agama Kristen. Ketika proses penyebaran Injil, negerinegeri yang memeluk agama Hindu kemudian menerima Injil dan menjadi Kristen. Walaupun tidak semua menerima Injil, tetapi sebagian masyarakat menerimanya karena mereka mengagap diri mereka "kafir" atau tidak beragama. Di sisi lain, mereka melindungi saudara Muslim untuk tidak menjadi Kristen.

\footnotetext{
22 Ibid., dilengkapi oleh Marthinus Manuele (Tokoh adat Makububui) dan Viktor Sinai (Tokoh adat Lumahpelu), dalam Wawancara, Taniwel Timur, 2020.

${ }^{23}$ Manuele, Wawancara, Taniwel Timur, 2020.
} 
Kekerabatan tetap dijaga ketika penginjil-penginjil pribumi menyebarkan Injil dan membangun sekolah-sekolah. Mereka tetap membiarkan anak-anak Muslim bersekolah di sekolah Kristen tanpa mengkristenkan mereka. Begitu juga dengan anak-anak Kristen yang bersekolah di sekolah Muslim, mereka tidak didoktrin dengan ajaran-ajaran Muslim. Dalam pemahaman masyarakat Taniwel Timur, "agama merupakan identitas yang datang kemudian, jauh sebelum itu kami telah hidup sebagai keluarga yang diikat secara adat." ${ }^{24}$ Dengan demikian perjumpaan Kristen dan Muslim di Taniwel Timur menjadi perjumpaan sosial yang ramah dan harmonis.

Kedua, pergolakan RMS 1950 menjadi bagian penting dalam sejarah keterlibatan masyarakat Muslim-Kristen di Taniwel Timur. Republik Maluku Selatan atau yang dikenal dengan sebutan RMS, merupakan kelompok gerakan kemerdekaan yang didirikan oleh Dr. Soumokil pada tahun 1950. Tujuan RMS adalah melepaskan Maluku dari Negara Kesatuan Republik Indonesia (NKRI) dan menjadikan Maluku sebagai negara merdeka. Namun demikian, upaya ini digagalkan oleh pemerintah Indonesia. Kegagalan ini kemudian menciptakan perang antara tentara RMS dengan Tentara Nasional Indonesia (TNI). Ketika RMS kalah melawan TNI, antek-antek RMS kemudian melarikan diri ke daerah pegunungan Pulau Seram. Tentara RMS dipimpin oleh Dr. Soumokil, kemudian membangun markas dan berdiam di pegunungan Pulau Seram.

Kedatangan RMS ke Pulau Seram memberikan ancaman bagi daerah-daerah yang berada di pegunungan. Masyarakat di daerah pegunungan dipaksa untuk menjadi tentara RMS, diculik dan disiksa bahkan dibunuh ketika menolak mengikuti RMS. Melihat keadaan tersebut, raja-raja di daerah pesisir Taniwel Timur dipimpin oleh Latu Kouwe, berupaya untuk memindahkan masyarakat yang berada di daerah pegunungan ke daerah pesisir. Latu Kouwe merupakan Raja negeri Sukaraja (negeri Muslim) yang pada waktu itu bermukim bersama-sama dengan Uweng Raya (Taniwel Timur) di daerah pesisir. Upaya ini dilakukan bersama dengan TNI untuk membantu masyarakat pegunungan terbebas dari penindasan RMS. Rencana ini membuahkan hasil yang baik sehingga negeri-negeri yang berada di pegunungan kemudian bermigrasi ke daerah pesisir. Negeri-negeri tersebut, di antaranya,

${ }^{24}$ Meute, Wawanccara, Taniwel Timur, 2020. 
yaitu Makububui, Seakase, dan Lumapelu. Mereka diberikan wilayah sebagai tempat tinggal dan lahan untuk bercocok tanam. Penerimaan ini dilakukan dengan baik, seperti halnya leluhur mereka melakukan penerimaan kepada utusan-utusan dulu (Sukaraja). ${ }^{25}$ Dengan demikian, kehidupan sosial Muslim-Kristen yang saling melindungi, saling menolong, saling menerima merupakan bagian yang sangat sentral dalam kehidupan masyarakat Taniwel Timur.

Ketiga, konflik etnik 1999 di Maluku, menjadi bagian puncak dari sejarah panjang kehidupan Muslim-Kristen di Taniwel Timur. Konflik kekerasan tahun 1999 merupakan sebuah sejarah kelam kehidupan Muslim-Kristen di Maluku. Namun demikian, konflik kekerasan 1999 menjadi bukti sejarah panjang kerukunan MuslimKristen di Taniwel Timur-Maluku. Hal ini disebabkan oleh keterlibatan masyarakat Taniwel Timur (Makububui, Sukaraja, Lumapelu dan Uweng), dalam menjaga relasi dan komunikasi yang baik di antara mereka. Upaya-upaya ini dilakukan melalui, di antaranya, sumpah adat orang basudara. Sumpah adat merupakan sebuah ikatan kekeluargaan yang dilakukan oleh masyarakat Muslim-Kristen untuk menjaga kerukunan, kedamaian, ketenangan, dan keharmonisan di antara mereka. Ikatan ini dilakukan dengan cara membuat sebuah ritual yang di dalamnya negeri-negeri di Taniwel Timur mengikat sumpah bahwa mereka satu keluarga. Hal ini dilakukan juga dengan mengingat penerimaan-penerimaan yang dilakukan oleh leluhur mereka pada zaman dulu.

Sumpah adat menjadi bagian sakral dalam kehidupan sosial masyarakat Taniwel Timur. Mereka tidak dapat mengingkari kepercayaan adat mereka dan tetap menjaga kesucian sumpah tersebut dengan tidak berlaku jahat kepada sesama mereka yang berbeda keyakinan. Sumpah adat tidak hanya mengikat orangorang yang memiliki hubungan genelogis saja, tetapi juga kepada semua orang yang telah diterima dan menjadi bagian dari negerinegeri adat di Taniwel Timur. Konsekuensi dari pengingkaran sumpah ini, pelaku dapat mengalami kematian secara mistis ataupun mendapat sanksi adat, yaitu dikeluarkan dari negeri. ${ }^{26}$

Upaya selanjutnya adalah membentuk "kelompok-kelompok jaga" di setiap desa untuk mengantisipasi pendatang luar atau

\footnotetext{
${ }^{25}$ Bada Sitania (Tokoh Adat Sukaraja), Wawancara, Taniwel Timur, 2020.

${ }^{26}$ Meute, dilengkapi oleh Manuele dan Sinai, Wawancara, Taniwel Timur, 2020.
} 
provokator dari luar. Anggota kelompok jaga ini terdiri dari masyarakat beragama Muslim dan Kristen dan ditempatkan di setiap desa. Upaya ini dilakukan melalui kesepakatan bersama di antara raja-raja dan masyarakat. Kelompok jaga ini dapat disebut sebagai kelompok perdamaian. Mereka bertugas untuk mengawasi setiap pendatang, meredakan rumor, dan menjadi informan pemerintah. Kelompok ini dibentuk sepanjang konflik kekerasan terjadi di Maluku. Upaya ini berhasil mengusir pendatang luar dengan tujuan provokasi, meniadakan rumor, dan menciptakan keamanan di Taniwel Timur. ${ }^{27}$

Selain sumpah adat dan kelompok jaga, upaya selanjutnya adalah membangun interaksi dan komunikasi di antara anggota masyarakat, sesama tokoh agama dan tokoh adat juga pemerintah desa. Komunikasi dan interaksi yang dilakukan secara intens dan teratur menciptakan suasana tenang dan saling percaya di antara masyarakat Muslim-Kristen Taniwel Timur. Interaksi dan komunikasi ini dilakukan dengan cara saling mengunjungi, mengadakan pertemuan di antara pemerintah desa, tokoh agama dan tokoh adat, makan bersama, anak-anak bermain bersama, bahkan bekerja sama dalam upaya menjaga keamanan desa-desa. ${ }^{28}$ Dengan demikian, melalui keterlibatan masyarakat seperti itulah, kedamaian dan ketentraman dapat dipertahankan ketika konflik 1999.

Keempat, Keterlibatan masyarakat Muslim-Kristen pada masa sekarang. Setelah sejarah panjang keterlibatan masyarakat Taniwel Timur dalam menjaga keharmonisan di tengah pluralitas, kedamaian itu tetap terlestarikan hingga sekarang. Pluralitas di Taniwel Timur tidak menjadi ancaman untuk berinteraksi, berkomunikasi atau hidup bersama. Relasi semacam ini dilatarbelakangi oleh kehidupan masyarakat yang saling terhubung satu dengan yang lain untuk tetap mengusahakan kehidupan bersama yang lebih baik. Hal ini diwujudkan dengan beberapa upaya, yaitu; komunitas orang basudara (kekeluargaan) yang diwujudkan dalam kehidupan setiap hari, dan kerja sama atau gotong royong yang dalam tradisi Maluku disebut masohi.

Berdasarkan fakta sosial, masyarakat Taniwel Timur merupakan masyarakat plural yang terdiri dari beberapa suku dan

${ }^{27}$ Ibid.

${ }^{28}$ Ibid. 
agama, namun mereka tetap hidup berdampingan dengan damai dan toleran. Kedamaian ini dilatarbelakangi oleh masyarakat Taniwel Timur yang selalu menjunjung tinggi nilai-nilai persaudaraan. Ikatan persaudaraan ini terbentuk karena hubungan genealogis, penerimaan secara adat, dan perkawinan campur. Bentuk nyata penghargaan ini dilakukan melalui interaksi setiap hari. Keluarga Muslim dan Kristen saling mengunjungi, saling berbagi makanan, saling membantu dan sebagainya. Kegiatan lain yang dilakukan juga ketika upacara-upacara adat seperti perkawinan dan kematian mereka saling membantu dan mengunjungi. ${ }^{29}$

Komunitas orang basudara ini juga diwujudkan dalam bentuk saling mengunjungi atau bersilaturahmi ketika hari-hari besar keagamaan seperti Natal, Idul Fitri, Tahun Baru, Maulid, dan sebagainya. Kebiasaan-kebiasaan ini tidak hanya terjadi dalam kehidupan setiap hari, tetapi juga diterapkan kepada anak-anak melalui ruang-ruang pendidikan. Ketika Natal, guru dan siswa-siswi Muslim turut mengambil bagian untuk mensukseskan perayaan Natal dengan menjadi panitia Natal atau pengisi acara. Hal yang sama juga ketika Sekolah merayakan Halal Bihalal, guru dan siswasiswi Kristen juga menjadi panitia serta pengisi acara. ${ }^{30}$ Secara sosiologis dapat dikatakan bahwa masyarakat Taniwel Timur hidup bersama sebagai komunitas sosial yang saling menerima, menghargai, menghormati, dan membaur satu dengan yang lain.

Sementara itu, masobi merupakan salah satu kegiatan saling membantu untuk meringankan beban pekerjaan. Masohi sendiri terbagi tiga yaitu; pertama, masohi ekonomi, yaitu kegiatan gotong royong yang berkaitan dengan kegiatan ekonomi, misalnya membantu membuka lahan untuk bercocok tanam, membudidayakan cengkeh dan kelapa, memanen hasil cengkeh, kelapa dan durian, membangun rumah, dan sebagainya. Kedua, masobi kultur, berupa kegiatan tolong menolong yang berhubungan dengan budaya, seperti pembangunan rumah adat, pembangunan sekolah, pembangunan balai desa, pembersihan desa, pembersihan pantai, pembersihan TPU (tempat pemakaman umum) dan kegiatan-

29 Japar Rumahera (Tokoh adat Desa Sukaraja), Wawancara, Taniwel Timur, 2020 .

30 Kustiana Petta (Tokoh Agama Kristen Desa Makububui), dilengkapi oleh Manap Sitania (Tokoh Agama Islam Desa Sukaraja), Wawancara, Taniwel Timur, 2020. 
kegiatan adat lainnya. Ketiga, masohi religius, merupakan kegiatankegiatan yang berhubungan dengan aktivitas keagamaan, misalnya pembangunan Gereja, pembangunan Masjid, ataupun renovasi pastori (rumah Pendeta). Selain itu, ketika Gereja Protestan Maluku (GPM) melakukan persidangan MPL Sinode di Desa Uweng, masyarakat Muslim Sukaraja turut membantu dengan menjadi panitia, menyediakan bahan makanan (ikan dan ayam), menjadi penerima tamu (perempuan-perempuan Muslim dari Sukaraja menggunakan kain gandong untuk menjemput tamu), membuat kelompok masak, dan sebagainya. ${ }^{31}$

Masohi atau gotong-royong merupakan sebuah sistem kerja masyarakat Taniwel Timur, yang cukup banyak membantu perekonomian masyarakat, kehidupan sosial, dan bahkan kehidupan keagamaan. Masobi merupakan tradisi yang pada dasarnya merupakan pekerjaan yang dilakukan bersama dengan sukarela. Namun setelah perkembangan zaman, nilai masobi ekonomi mulai bergeser menjadi sistem kerja dengan mendapatkan upah. Walaupun demikian sistem ini tidak berlaku dalam kegiatankegiatan keagamaan dan adat. Dengan masohi, masyarakat Taniwel Timur dapat saling merasakan beban sesama dan saling bahumembahu untuk menyelesaikan suatu pekerjaan.

\section{Keterlibatan Masyarakat Muslim-Kristen sebagai Basis Harmoni Sosial di Taniwel Timur}

Keterlibatan masyarakat mengacu pada cara-cara di mana masyarakat berpartisipasi dalam kehidupan komunitas untuk meningkatkan kondisi orang lain atau membantu membentuk masa depan komunitas. Keterlibatan masyarakat bertujuan untuk menciptakan kedamaian dan kehidupan yang saling menguntungkan dalam sebuah komunitas atau di antara komunitaskomunitas. Keterlibatan masyarakat selalu berhubungan dengan kesukarelaan, filantropi, dan altruisme. Kelompok-kelompok masyarakat yang memiliki tingkat keterlibatan masyarakat yang tinggi dapat menciptakan kehidupan masyarakat yang lebih baik dan harmonis.

Keterlibatan masyarakat Muslim-Kristen di Taniwel Timur, Maluku terbagi ke dalam dua kegiatan yaitu; pertama, keterlibatan secara formal (Putnam) atau keterlibatan asosiasi (Varshney).

${ }^{31}$ Meute, Wawancara, Taniwel Timur, 2020. 
Keterlibatan formal atau asosiasi ini terlihat dari kegiatan-kegiatan yang dilakukan oleh masyarakat Taniwel Timur seperti memiliki sebuah ikatan adat orang basudara. Ikatan orang basudara ini memfasilitasi interaksi dan komunikasi di antara masyarakat Muslim-Kristen di Taniwel Timur. Masyarakat Taniwel Timur meyakini keberadaan mereka bukan sebagai kelompok-kelompok yang berbeda secara suku dan agama, tetapi menjadi satu sebagai sebuah ikatan kekeluargaan. Sehingga wujud dari ikatan kekeluargaan ini mereka dapat berinteraksi dengan bebas, saling menolong, menghargai, mengunjungi, dan melindungi tanpa merasa terintimidasi atau kuatir seperti terjadi pada daerah-daerah lain di Maluku.

Kedua, keterlibatan formal yang diwujudkan dalam dunia kerja. Mayoritas mata pencaharian masyarakat Taniwel Timur adalah bercocok tanam, nelayan, berdagang, dan tukang bangunan. Dalam melakoni pekerjaan ini tidak semua orang dapat melakukannya sendiri, sehingga membutuhkan bantuan orang lain. Dalam relasi kerja inilah hubungan masyarakat Muslim-Kristen dapat terlihat. Kerja sama yang baik terlihat terutama ketika pembangunan rumah ibadah (Masjid dan Gereja), pastori, sekolah, rumah penduduk, dan perkantoran. Pembagian kerja dilakukan berdasarkan kebutuhan, ketika Sukaraja membangun Masjid maka negeri-negeri Kristen turut membantu, begitu juga ketika pembangunan Gereja, sekolah, rumah, dan sebagainya. Selain dalam pembangunan, hal yang sama juga terjadi pada sektor kerja yang lain seperti bercocok tanam, memanen hasil, menangkap ikan, dan lain sebagainya. Dalam proses kerjasama ini, baik Muslim atau Kristen akan saling membantu menyelesaikan pekerjaan. Kerja sama yang baik ini terjadi di antara Muslim-Kristen tanpa melihat latar belakang agama dan suku, tetapi yang diutamakan adalah kepercayaan, kecakapan, dan kemampuan pada bidang yang dibutuhkan.

Ketiga, keterlibatan formal kegiatan adat-istiadat. Tradisi atau adat istiadat yang sangat kental menjadi salah satu pengikat bagi hubungan Muslim-Kristen di Taniwel Timur. Masyarakat MuslimKristen selalu menjalankan tradisi dengan baik, seperti adat pelantikan Raja. Negeri Muslim (Sukaraja) memiliki tugas untuk menyiapkan Misloit atau Surat Keputusan (SK) Raja yang kemudian akan diberikan kepada negeri-negeri yang baru dilantik rajanya. Tugas menyiapkan dan memberikan Misloit (SK Raja), merupakan 
tugas sakral secara adat yang dikhususkan kepada negeri Sukaraja sebagai bentuk penghargaan. Penghargaan ini dilatarbelakangi oleh jasa leluhur Sukaraja yang telah membawa kedamaian di antara penduduk asli pada masa lampau. Tradisi pemberian Misloit ini sangat sakral sehingga tidak dapat diberikan oleh negeri lain selain negeri Sukaraja. Ketika terjadi kesalahan dalam proses adat ini maka orang-orang yang terlibat dapat mengalami kesialan atau mendapat hukuman adat.

Tradisi yang lain juga yang sangat kental dan mengikat yaitu tradisi yang berkaitan dengan siklus kehidupan. Tradisi ketika prosesi kelahiran, pernikahan dan kematian harus dilakukan secara adat dan melibatkan setiap anggota masyarakat. Dalam pernikahan adat setiap orang akan ikut mengambil bagian dalam prosesi adat tersebut, tanpa membedakan suku dan agama. Perayaan ini menjadi perayaan bersama dan sukacita bersama sehingga setiap orang turut mengambil bagian dalam proses tersebut. Poin yang sama juga dilakukan ketika upacara kelahiran dan kematian. Dengan demikian, adat istiadat menjadi media bagi masyarakat Muslim-Kristen untuk berinteraksi dan berkomunikasi sekaligus terlibat secara langsung dan aktif dalam kehidupan bersama.

Keempat, keterlibatan masyarakat yang dimaksud diwujudkan melalui partisipasi masyarakat dalam membantu pemerintah desa. $\mathrm{Hal}$ ini terlihat dalam kegiatan-kegiatan desa yang dilakukan secara bersama, seperti musyawarah desa yang dilakukan secara bersamasama dengan tujuan untuk memecahkan masalah-masalah setiap desa di Taniwel Timur. Dalam kegiatan seperti ini, baik masyarakat Muslim atau Kristen memiliki utusan untuk menyampaikan aspirasi rakyat kepada pemerintah desa. Kegiatan selanjutnya adalah kerjasama dalam pembangunan desa seperti pembersihan desa (cuci negeri), pembersihan pantai dan TPU, pembangunan gedunggedung pemerintah desa dan sebagainya; utusan-utusan dari anggota masyarakat yang secara sukarela ditugaskan membantu menjaga keamanan desa-desa baik Muslim maupun Kristen; keterlibatan masyarakat dalam mengikuti pemilihan umum, mereka akan saling berdiskusi untuk menentukan calon pemimpin yang dapat membawa perubahan baik bagi masyarakat. Terkadang dalam proses yangg terakhir ini banyak perbedaan pendapat, namun mereka selalu berusaha untuk menciptakan ketentraman. 
Keterlibatan masyarakat yang kedua menurut Putnam dan Varshney yaitu keterlibatan informal atau non-asosiasi. Keterlibatan ini merupakan aktivitas setiap hari yang dilakukan oleh masyarakat Muslim-Kristen di Taniwel Timur. Kegiatankegiatan ini meliputi; Pertama, interaksi dan komunikasi yang dilakukan ketika bertemu di jalan, pasar, dan kebun. Interaksi ini dibangun untuk sekadar menyapa, menanyakan kabar, berkomunikasi tentang aktivitas yang sementara dilakukan ataupun lebih intens kepada curhat dan sebagainya. Kedua, saling mengunjungi satu dengan yang lain. Aktivitas ini dilakukan ketika acara syukuran, ulang tahun, pernikahan, kematian, dan sebagainya. Aktivitas ini dilakukan tentunya dengan tujuan membantu atau merayakan bersama, memberi perhatian, dan simpati/empati. Ketiga, bersilaturahmi ketika hari raya keagamaan. Masyarakat Taniwel Timur memiliki kebiasaan untuk saling mengunjungi ketika hari raya, seperti Natal; umat Muslim akan menyediakan kue untuk dibagikan kepada umat Kristen yang merayakan, mereka juga akan mengikuti syukuran Natal ataupun perayaan-perayaan Natal yang dilakukan oleh umat Kristen. Sama halnya juga dengan Idul Fitri atau Maulid, umat Kristen akan menyediakan bahan makanan seperti daging sapi, ayam, pisang, dan ubi-ubian kemudian diberikan kepada umat Muslim. Selain itu juga mereka akan saling mengunjungi dan merayakan bersama-sama. Semua aktivitas ini dilakukan dengan kesadaran bahwa mereka adalah orang basudara (keluarga) terlepas dari apa suku dan agama mereka.

Kehidupan sosial masyarakat Taniwel Timur secara nyata telah menciptakan civil sphere atau ruang sipil di mana kedamaian, toleransi, solidaritas dan persaudaraan diciptakan. Keterlibatan masyarakat yang dilakukan oleh Muslim-Kristen di Taniwel merupakan kegiatan yang dilakukan berdasarkan: Pertama, nilai persaudaraan. Keterlibatan masyarakat Muslim Kristen didasarkan pada kesadaran bahwa mereka adalah orang basudara. Orang basudara memiliki arti yang sangat dalam lebih dari sekedar hubungan kekeluargaan yang didasarkan pada hubungan biologis. Orang basudara mengacu pada ikatan kekeluargaan yang lebih kental dari ikatan darah, mereka saling menerima, mendukung, menghargai, menjaga, mengasihi, menolong dan sebagainya. Dengan demikian, nilai persaudaraan inilah yang menjadi dasar dari keterlibatan masyarakat Muslim-Kristen di Taniwel Timur, tetapi 
juga menjadi tujuan keterlibatan masyarakat itu sendiri yaitu untuk menciptakan ikatan kekeluargaan yang erat.

Kedua, saling percaya (mutual trust) menjadi nilai penting dalam membangun hubungan sosial yang harmonis. Keterlibatan masyarakat Muslim-Kristen dalam kehidupan sosial mereka didasarkan pada kepercayaan bahwa mereka bersaudara dan saudara harus saling melindungi, mengasihi, dan menghargai. Nilai kepercayaan inilah yang membuat masyarakat Muslim-Kristen saling menerima dan dapat hidup berdampingan. Hal ini membuat mereka dapat berinteraksi dan berkomunikasi tanpa peduli dengan identitas etnik mereka yang berbeda. Mereka makan bersama karena tidak takut dibunuh, kerja bersama karena tidak takut dirugikan, hidup bersama karena tidak takut disakiti atau dilukai bahkan ketika konflik yang sangat parah. Keterlibatan ini terjadi karena saling percaya satu dengan yang lain antara anggota masyarakat Taniwel Timur.

Ketiga, kesamaan nasib yang dialami oleh masyarakat MuslimKristen sebagai pendatang dan penduduk asli yang saling menerima, melalui masa-masa sulit ketika kolonialisme Belanda, pergolakan RMS, sampai pada Konflik 1999. Perasaan ini menciptakan ikatan yang kuat, bahwa mereka saling terlibat dalam kehidupan satu dengan yang lain. Perasaan terlibat dalam kehidupan bersama (kesamaan nasib) membangun sebuah komitmen untuk terus membentuk hubungan yang saling mendukung. Keterlibatan masyarakat karena perasaan kesamaan nasib ini juga, dilakukan dengan tujuan menciptakan ikatan kekeluargaan yang kuat di antara Muslim-Kristen. Oleh karena itu, hubungan dan perasaan tersebut tidak dapat dihancurkan oleh masalah atau konflik apapun di masa depan.

Keempat, keterlibatan masyarakat Taniwel Timur dalam sebagian besar aspek kehidupan sosial budaya mereka dikarenakan perasaan aman/damai. Muslim-Kristen di Taniwel Timur merasa damai ketika mereka bekerja bersama, berjumpa dan berdiskusi bersama, mengikuti tradisi-tradisi keagamaan dan adat istiadat bersama, saling menjaga dan melindungi serta menghargai perbedaan-perbedaan yang mereka miliki. Perasaan aman dan damai ini menjadikan mereka masyarakat yang secara individu peduli dan peka terhadap keberadaan orang lain. Tidak hanya untuk melindungi diri mereka sendiri atau komunitas keagamaan 
mereka tetapi melindungi semua orang yang menjadi sesama mereka. Sesama bagi masyarakat Taniwel Timur adalah setiap orang yang dengan tangan terbuka mau menjadi saudara atau menjadi orang basudara.

Keterlibatan masyarakat di antara negeri-negeri ini memiliki tujuan untuk tetap menjaga kedamaian yang telah diupayakan oleh leluhur mereka dahulu, masa sekarang, dan masa depan. Dengan demikian, di antara kedua jenis keterlibatan masyarakat, baik formal maupun informal memiliki pengaruh, nilai dan tujuan yang sama dan tidak ada yang lebih unggul. Dengan keterlibatan masyarakat Taniwel Timur dalam berinteraksi, berkomunikasi dan terlibat satu sama lain dalam kehidupan sosial telah menciptakan ruang sipil di mana solidaritas, toleransi, persaudaraan dan kedamaian diperoleh masyarakat. Dengan kata lain, keterlibatan masyarakat yang dilakukan oleh masyarakat Muslim-Kristen ini menciptakan harmoni dalam kehidupan sosial masyarakat Taniwel Timur.

\section{Penutup}

Keterlibatan masyarakat merupakan tindakan individu dan kolektif yang dirancang untuk mengidentifikasi dan menangani masalah-masalah yang menjadi perhatian publik. Keterlibatan masyarakat ini dapat terjadi dalam bentuk kesukarelaan individu atau kelompok, baik dalam bentuk keterlibatan formal maupun informal. Aktivitas ini juga mencakup upaya secara langsung dalam mengatasi masalah melalui interaksi dan komunikasi dengan berbagai pihak. Sehingga keterlibatan masyarakat mencakup berbagai kegiatan spesifik seperti saling mengunjungi dan makan bersama sampai pada membentuk komunitas antikonflik. Keterlibatan masyarakat seperti ini, juga terjadi dalam kelompokkelompok Muslim-Kristen di Taniwel Timur yang berkolaborasi untuk menciptakan ruang solidaritas, persaudaraan, keakraban dan keadilan di mana dapat menghasilkan kehidupan sosial yang jauh dari ketegangan etnis atau sampai pada konflik kekerasan.

Keterlibatan masyarakat Muslim-Kristen di Taniwel Timur, dibedakan ke dalam dua kelompok, yang pertama yaitu keterlibatan secara formal yang dilakukan di ruang-ruang terorganisir seperti pemerintahan desa, lembaga adat/budaya dan lembaga agama. Keterlibatan kedua yaitu secara informal yang dilakukan di antara keluarga Muslim-Kristen, saling mengunjungi, makan bersama, 
membantu dan menolong, merayakan festival atau hari-hari raya bersama. Kedua bentuk keterlibatan yang terjadi di dalam masyarakat Taniwel Timur, memiliki manfaat yang sama yang dilakukan dengan mengutamakan rasa kerelaan, filantropi, dan altruisme. Dengan demikian, masyarakat Muslim-Kristen di Taniwel Timur dapat membangun hubungan sosial yang harmonis pada masa lalu dan masa sekarang.

\section{Daftar Rujukan}

Alexander, Jeffrey C. The Civil Sphere. New York: Oxford University Press, 2006.

Bartels, Dieter. Di Bawah Naungan Gunung Nunusaku; Muslim Kristen Hidup Berdampingan di Maluku Tengah Jilid I: Kebudayaan. Jakarta: Kepustakaan Populer Gramedia, 2017.

----. Di Bawah Naungan Gunung Nunusaku; Muslim Kristen Hidup Berdampingan di Maluku Tengah Jilid II: Sejarah. Jakarta: Kepustakaan Populer Gramedia, 2017.

Bourdieu, Piere dan James S. Coleman. Social Theory for Changing Society. New York: Westview Press, 1991.

Burke, Peter J. dan Jan E. Stets. Identity Theory. New York: Oxford University Press, 2009.

Creswell, John. Research Design: Pendekatan Metode Kualitatif, Kuantitatif dan Campuran. Yogyakarta: Pustaka Pelajar, 2014.

Daniela, N. Lusier dan M Steven Fish. "Indonesian: The Benefits of Civic Engagement," Journal of Democracy, Vol. 23, No. 1, 2012.

Doolittle, Ami dan Anna C. Faul. "Civic Engagement Scale: A Validation Study," SAGE Open, Vol. 3, No. 3, 2013.

Gerardette, Philips. Melampaui Pluralisme. Malang: Madani, 2016.

Handoko, Wuri. "Islamisasi dan Perkembangan Kerajaan Hoamoal di Seram Bagian Barat," KAPATA Arkeolog, Vol. 10, No. 2, 2014.

Lattu, Izak Y. M. "Culture and Christian-Muslim Dialogue in Moluccas-Indonesia," Interreligious Insight, Vol. 10, No. 1, 2012.

----. "Orality and Interreligious Relationship: The Role of Collective Memory in Christian-Muslim Engagements in Maluku, Indonesia." Disertasi--The Graduate Theological Union, Berkeley, 2014.

Lawang, Robert. Kapital Sosial dalam Perspektif Sosiologik Suatu Pengantar. Jakarta: FISIP UI Press, 2004. 
Maleong, Lexy. J. Metode Penelitian Kualitatif. Bandung: Remaja Karya, 1989.

Morris, Aldon. "Naked Power and Civil Sphere Review Jeffrey Alexander 'The CIVIL Sphere," The sociological Quarterly, Vol. 48, No. 4, 2007.

Nikolas, Abercrombie. Kamus Sosiologi. Yogyakarta: Pustaka Pelajar, 2010.

Payitno, H. A. Etika Kemajemukan; Solusi Strategis Merenda Kebersamaan dalam Bingkai Masyarakat Majemuk. Jakarta: Penerbit Universitas Trisakti, 2004.

Putnam, Robert. "Tuning In Tuning Out: The Strange Disappearance of Social Capital in America," Journal Political Science and Politics, Vol. 28, No. 4, 1995.

Putnam, Robert. Making Democracy Work: Civic Traditions in Modern Italy. New Jersey: Princeton University Press, 1993.

Putnam, Roberth. Bowling Alone: The Collapse and Revival of American Community. New York: Simon \& Schuster, 2000.

Richard, Adlar P. dan Judy Goggin. "What Do We Mean By 'Civic Engagement?,"' Journal of Transformative Education, Vol. 3, No. 3, 2005.

Soumokil, Tinji. Reintegrasi Sosial Pasca Konflik Maluku. Salatiga: Fakultas Ilmu Sosial dan Komunikasi UKSW, 2011.

Varshney, Ashutosh. Ethnic conflict and Civic Life: Hindu and Muslims in India. London: Yale University Press, 2002.

\section{Wawancara}

Danie Meute. Wawancara. Taniwel Timur, 08 Januari 2020.

Marthinus Manuele. Wawancara. Taniwel Timur, 08 Januari 2020.

Viktor Sinai. Wawancara. Taniwel Timur, 08 Januari 2020.

Bada Sitania. Wawancara. Taniwel Timur, 13 Januari 2020.

Japar Rumahera. Wawancara. Taniwel Timur, 13 Januari 2020.

Kustiana Petta. Wawancara. Taniwel Timur, 12 Januari 2020.

Manap Sitania. Wawancara. Taniwel Timur, 13 Januari 2020. 